\title{
Perbandingan Efektivitas antara Probiotik Hidup dengan Probiotik Mati pada Anak dengan Malahsorpsi Laktosa
}

\author{
Novie Homenta Rampengan, Jeannette Irene Chirstie Manoppo, Sarah Maria Warouw \\ Bagian Ilmu Kesehatan Anak FK UNSRAT/RSUP Prof. R.D. Kandou Manado
}

\begin{abstract}
Latar belakang. Malabsorpsi laktosa merupakan kondisi paling sering menyebabkan gizi kurang pada anak, karena laktosa tidak dapat dihidrolisis secara sempurna di usus halus. Probiotik merupakan suplemen makanan yang dapat memberikan keuntungan pada pasien dengan malabsorpsi laktosa, tetapi belum jelas apakah probiotik hidup atau probiotik mati lebih efektif.

Tujuan. Menentukan efektivitas probiotik hidup dan probiotik mati dengan melakukan Uji Hidrogen Napas setelah diberi probiotik.

Metode. Uji klinis dengan desain sebelum dan sesudah diberi perlakuan di lima Sekolah Dasar Negeri (SDN) di Kecamatan Tuminting, Manado selama bulan Maret sampai Mei 2008. Kriteria inklusi anak sehat umur 10-12 tahun, status gizi $\geq 90 \%$ menurut kriteria Center of Disease Control (CDC) dan UHN $\geq 20$ part per million (ppm). Dilakukan pengacakan sederhana pada anak dengan malabsorpsi laktosa.

Hasil. Terdapat 130 anak yang diperiksa, 86 anak memenuhi kriteria di bagi dua tiap kelompok, namun hanya 39 anak kelompok probiotik hidup dan 40 anak kelompok probiotik mati dapat menyelesaikan studi. Terdapat perbedaan bermakna dari UHN menit ke-120 sebelum dan sesudah pemberian probiotik hidup dan probiotik mati pada anak dengan malabsorpsi laktosa $(p<0,001)$. Ketika kedua kelompok dibandingkan, tidak terdapat perbedaan pada UHN menit ke-120 sesudah pemberian probiotik hidup dan probiotik mati $(p=0,453)$.

Kesimpulan. Pemberian probiotik hidup dan probiotik mati selama 2 minggu dapat menurunkan nilai UHN pada anak dengan malabsorpsi laktosa, namun tidak terdapat perbedaan efektivitas antara kedua kelompok serta tidak dijumpai efek samping selama studi. (Sari Pediatri 2009;11(4):250-6).
\end{abstract}

Kata kunci: probiotik hidup, probiotik mati, malabsorpsi laktosa

\footnotetext{
Alamat korespondensi

Dr. Novie Homenta Rampengan, SpA. Bagian Ilmu Kesehatan Anak FK UNSRAT/RSUP Prof. R.D. Kandou Manado. Jl. Raya Tanawangko, Manado 95263, Indonesia. Telp 62-431-821652; Fax. 62-431-859091 Email : novierampengan@yahoo.com,novierampengan@hotmail.com
}

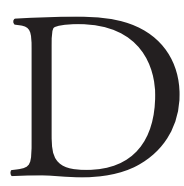
isakarida sukrosa dan laktosa adalah paling penting dalam susunan makanan yang mengandung karbohidrat. ${ }^{1}$ Laktosa terdapat pada susu makhluk yang menyusui seperti air susu ibu (ASI) yang merupakan 
sumber kalori. ${ }^{2,3}$ Malabsorpsi laktosa merupakan kondisi paling sering terjadi disebabkan karena kekurangan enzim laktase yang disebabkan adanya kerusakan epitel mukosa usus halus. ${ }^{4-6}$ Malabsorpsi laktosa dapat didiagnosis berdasarkan gejala intoleransi laktosa (riwayat borborigmic, sering flatus, kembung, mual, muntah, nyeri perut, diare) dan uji hidrogen napas (UHN) $\geq 20$ part per million (ppm). Aktivitas enzim laktase mulai terdeteksi pada bulan ketiga kehamilan dan mencapai puncak pada bayi berusia 2-4 minggu. ${ }^{2,7}$ Aktivitas enzim laktase bayi kurang bulan akan sama dengan bayi cukup bulan pada umur 2 minggu jika mendapat ASI dan aktivitasnya bertahan selama menyusui. ${ }^{7}$ Adapun tata laksana pada malabsorpsi laktosa maupun intoleransi laktosa yaitu dengan pemberian susu bebas laktosa, yoghurt atau susu fermentasi, probiotik, dan enzim laktase. $2,4,5,8$ Paling sering digunakan untuk mengatasi defisiensi laktase primer dan sekunder yaitu diet rendah laktosa atau bebas laktosa. ${ }^{4}$

Probiotik, terutama dari spesies Lactobacillus dan Bifidobacterium yang biasa digunakan pada susu fermentasi dapat mengurangi atau meringankan kondisi malabsorpsi ataupun intoleransi laktosa karena dapat memproduksi antibiotik alamiah yang dapat mengeleminasi berbagai macam kuman patogen gram negatif, meningkatkan aktivitas enzim laktase di usus dan dapat memfermentasi laktosa. ${ }^{9-12}$ Susu yang mengandung probiotik dengan strain yang tepat dan jumlah yang cukup dapat dijadikan alternatif bagi diet pasien malabsorpsi laktosa maupun intoleransi laktosa. ${ }^{13}$

Dehkordi $\mathrm{dkk}^{14}$ membandingkan efektivitas antara susu yang mengandung Lactobacillus Acidophilus dan Bifidobacterium, susu yang mengandung Lactobacillus tipe 1 dan susu yang mengandung Lactobacillus tipe 2 dan mereka mendapatkan nilai UHN yang negatif tanpa gejala intoleransi laktosa pada semua kelompok. Pada tahun 1997 Mustapha ${ }^{15}$ di Turki menambahkan Lactobacillus acidophilus pada makanan yang tidak difermentasi dan mendapatkan hasil UHN positif dengan gejala intoleransi laktosa. Pada tahun 2005, Arifin $\mathrm{dkk}^{16}$ di Jakarta melakukan penelitian terhadap 42 murid Sekolah Lanjutan Tingkat Pertama Negeri (SLTPN) dengan gejala intoleransi laktosa, mereka diberi minum susu dengan probiotik selama dua minggu dan mendapatkan bahwa gejala intoleransi laktosa menghilang 95\% dengan hasil UHN positif menjadi negatif pada $85,7 \%$ murid.
Pada tahun 2006 Warouw $\mathrm{dkk}^{17}$ di Manado melakukan penelitian efektivitas probiotik hidup (Lacbon) dan probiotik mati (Dialac) pada pasien diare akut umur 4-60 bulan dan mendapatkan bahwa tidak ada perbedaan bermakna dalam frekuensi diare dan lama kesembuhan pada kedua kelompok. Tlaskal $\mathrm{dkk}^{18}$ di Praha melakukan penelitian penggunaan probiotik hidup dan probiotik mati pada anak dengan diare akut dan mendapatkan bahwa probiotik hidup (Lacidofil) dapat mengurangi lama diare dan gejala klinik diare dibandingkan dengan probiotik mati. Xiao $\mathrm{dkk}^{19}$ di China melaporkan pada pasien diare kronik dewasa didapatkan probiotik mati lebih baik daripada probiotik hidup dalam hal mengurangi gejala nyeri abdominal, distensi abdomen, dan memperbaiki konsistensi tinja. Sampai sekarang, tidak ada penelitian yang membandingkan efektivitas probiotik hidup dengan probiotik mati sebagai terapi pada anak dengan malabsorpsi laktosa atau intoleransi laktosa. Dengan latar belakang tersebut, peneliti melakukan penelitian tentang perbandingan efektivitas probiotik hidup dengan probiotik mati pada anak dengan malabsorpsi laktosa.

\section{Metode}

Penelitian uji klinis dengan desain sebelum dan sesudah diberi perlakuan pada anak dengan riwayat intoleransi laktosa (riwayat borborigmic, sering flatus, kembung, mual, muntah, sakit perut, diare) atau malabsorbsi laktosa yang dideteksi dengan pemeriksaan UHN. Jumlah subjek minimal 35 anak tiap kelompok penelitian $(\alpha=0,05$; power $80 \% ; S=2.5 \mathrm{ppm} ; \mathrm{d}=1,05$ ppm), ${ }^{20}$ dilakukan di SDN di Kecamatan Tuminting sejak 1 Maret sampai dengan 3 Mei 2008 (9 minggu). Dengan menggunakan multistage sampling, kami mendapatkan lima SDN yaitu SDN 114, SDN 46, SDN 19, SDN 22, dan SDN 111 dari 33 SDN di Kecamatan Tuminting, Manado.

Subjek penelitian adalah anak-anak SDN di Kecamatan Tuminting yang menderita malabsorbsi laktosa. Kriteria inklusi adalah anak usia 10-12 tahun sehat (kelas V dan VI), penilaian status gizi berdasarkan Center for Disease Control (CDC) $\geq 90 \%$, nilai $U H N \geq 20$ ppm dan orang tua atau wali menandatangani informed consent. Anak tidak diikutsertakan dalam penelitian apabila dalam 1 minggu terakhir mendapat suplemen yang mengandung probiotik, 
mendapat antibiotik (kanamycin, neomycin, colhisin), methothrexate, acetyl salicylic acid, metochlorpramide, laxative, terapi radiasi 1 minggu terakhir, dan mengalami penyakit pernapasan atau saluran cerna (diare persisten). Semua pasien akan dievaluasi oleh peneliti utama. Protokol penelitian telah disetujui oleh Komite Etik Fakultas Kedokteran Universitas Sam Ratulangi.

Status gizi anak dinilai dengan mengukur berat badan (BB) dan tinggi badan (TB) menurut kartu pertumbuhan. Interpretasi status gizi berdasarkan $\mathrm{BB}$ di bagi TB menurut CDC. ${ }^{21}$

Penelitian UHN laktosa digunakan untuk menentukan malabsorbsi laktosa dengan cara yang tidak invasif. Sesudah berpuasa minimal 6 jam, sampel napas dikumpulkan menggunakan portable LCD 4 digit Lactometer versi 1.0 CvO-HLMT (Hoek Loos, Netherlands) pada menit ke 0, 30, 60, 90, dan 120 sesudah meminum larutan laktosa (2 g/kgbb: maximum $50 \mathrm{~g}$ ) dalam konsentrasi $20 \%$ maksimal dalam $250 \mathrm{ml}$ air. Malabsorpsi laktosa didefinisikan sebagai peningkatan konsentrasi hidrogen $\geq 20 \mathrm{ppm}$, di atas nilai dasar yang ditetapkan sebagai hasil yang positif pada menit ke 60,90 , dan $120 .{ }^{22}$

Anak dengan malabsorpsi laktosa dirandom ke dalam kelompok probiotik hidup atau kelompok probiotik mati. Kelompok probiotik hidup mendapat 1 kapsul ('Lacidofil) sekali dalam sehari selama 2 minggu dan kelompok probiotik mati mendapat 2 sachet
( ${ }^{\mathrm{C} D i a l a c)}$ sekali dalam sehari selama 2 minggu. Mereka kemudian diamati jika terdapat gejala intoleransi laktosa dan efek samping probiotik hidup maupun probiotik mati. Dua minggu kemudian, mereka diminta melakukan kembali UHN dengan cara yang sama dengan yang dilakukan sebelumnya.

Nilai UHN dibandingkan sebelum dan sesudah pemberian probiotik pada menit ke-120 pada anak dengan malabsorpsi laktosa. Data dianalisis menggunakan program komputer Statistical Package Software (SPSS 15). Analisis data yang digunakan adalah uji t berpasangan dan uji t independen.

\section{Hasil}

Subjek penelitian 130 anak, 86 (66,5\%) menderita laktosa malabsorpsi namun hanya 79 anak menyelesaikan penelitian ini, terdiri dari 39 anak dari kelompok probiotik hidup dan 40 anak dari kelompok probiotik mati. Rasio laki-laki berbanding perempuan adalah hampir sama (41 laki-laki : 38 perempuan). Tujuh anak putus studi karena menderita sakit saluran pernapasan atau saluran cerna (diare persisten) selama periode studi ini, terdiri dari 4 anak dari kelompok probiotik hidup dan 3 anak dari kelompok probiotik mati. Ditemukan 36 anak (92,3\%) dari kelompok probiotik hidup dan 32 anak (80\%) dari kelompok probiotik mati mempunyai status gizi baik. Data status

Tabel 1. Distribusi anak berdasarkan status gizi dan tipe dari probiotik

\begin{tabular}{lccc}
\hline Status Gizi & Probiotik hidup $(\%)$ & Probiotik mati $(\%)$ & Total $(\%)$ \\
\hline Baik & $36(52,9)$ & $32(47,1)$ & $68(100)$ \\
Berlebihan & $1(20,0)$ & $4(80,0)$ & $5(100)$ \\
Obesitas & $2(33,3)$ & $4(66,7)$ & $6(100)$ \\
\hline Total & $39(49,4)$ & $40(50,6)$ & $79(100)$ \\
\hline
\end{tabular}

Tabel 2. Gejala klinis sebelum pemberian probiotik

\begin{tabular}{lccc}
\hline Gejala & Probiotik hidup $(\%)$ & Probiotik mati $(\%)$ & Total $(\%)$ \\
\hline Nyeri perut & $26(66,7)$ & $29(725)$ & $55(69,6)$ \\
Muntah & $1(2,6)$ & $0(0)$ & $1(1,3)$ \\
Kembung & $1(2,6)$ & $0(0)$ & $1(1,3)$ \\
Diare & $1(2,6)$ & $0(0)$ & $1(1,3)$ \\
Lebih dari 1 gejala & $3(7,6)$ & $7(17,5)$ & $10(12,6)$ \\
Tanpa gejala & $7(17,9)$ & $4(10,0)$ & $11(13,9)$ \\
\hline Total & $39(100)$ & $40(100)$ & $79(100)$ \\
\hline
\end{tabular}


Novie Homenta Rampengan dkk: Efektivitas probiotik hidup dan probiotik mati malabsorpsi laktosa

Tabel 3. Gejala klinis sesudah pemberian probiotik

\begin{tabular}{lccc}
\hline Gejala & Probiotik hidup $(\%)$ & Probiotik mati $(\%)$ & Total $(\%)$ \\
\hline Nyeri perut & $11(28,2)$ & $12(30,0)$ & $23(29,1)$ \\
Mual & $0(0)$ & $1(2,5)$ & $1(1,3)$ \\
Kembung & $1(2,6)$ & $2(5,0)$ & $3(3,8)$ \\
Flatus & $0(0)$ & $1(2,5)$ & $1(1,3)$ \\
Lebih dari 1 gejala & $2(5,1)$ & $3(7,5)$ & $5(6,3)$ \\
Tanpa gejala & $25(64,1)$ & $21(52,5)$ & $46(58,2)$ \\
\hline Total & $39(100)$ & $40(100)$ & $79(100)$ \\
\hline
\end{tabular}

Tabel 4. Hasil pengujian uji hidrogen napas (UHN) sebelum dan sesudah pemberian probiotik

\begin{tabular}{lcccc}
\hline Kelompok & Menit & Rerata (SD) & T & $p$ \\
\hline $\begin{array}{l}\text { Probiotik hidup } \mathrm{n}=39 \\
\quad \text { Sebelum }\end{array}$ & 120 & & & \\
$\quad$ & & $24,51(10,35)$ & 9,556 & $<0,001$ \\
$\quad$ Sesudah & 120 & & & \\
$\begin{array}{l}\text { Probiotik mati } \mathrm{n}=40 \\
\quad \text { Sebelum }\end{array}$ & & $36,00(10,18)$ & 8,545 & $<0,001$ \\
$\quad$ Sesudah & 120 & $20,30(8,86)$ & & \\
$\begin{array}{l}\text { Probiotik hidup dan mati }(\mathrm{n}=39, \mathrm{n}=40) \\
\quad \text { Sebelum }\end{array}$ & & $22,13(12,41)$, & 0,755 & 0,453 \\
$\quad$ Sesudah & & $20,30(8,86)$ & & \\
\hline
\end{tabular}

gizi tertera pada Tabel 1.

Gejala malabsorpsi laktosa pada anak sebelum pemberian probiotik tertera pada Tabel 2. Secara keseluruhan, kami mendapatkan 55 anak $(69,6 \%)$ mengeluh nyeri perut, 11 anak $(13,9 \%)$ tidak mempunyai keluhan dan 10 anak (12,6\%) mempunyai lebih dari satu gejala. Distribusi gejala malabsorpsi laktosa pada anak sesudah pemberian probiotik tertera pada Tabel 3. Dijumpai 46 anak $(58,2 \%)$ tidak mempunyai keluhan, 23 anak $(29,1 \%)$ mengeluh nyeri perut dan 5 anak (6,3\%) mempunyai lebih dari satu gejala.

Hasil pengujian nilai rata-rata UHN pada menit ke-120 sesudah pemberian laktosa dan sebelum pemberian probiotik hidup 34,51 (SD 10,35) dan nilai rata-rata UHN pada menit ke-120 sesudah pemberian laktosa dan sesudah pemberian probiotik hidup menurun ke 22,13 (SD 12,41). Hasil uji statistik menggunakan uji t-berpasangan didapatkan perbedaan bermakna $(p<0,001)$ (Tabel 4). Hasil pengujian nilai rata-rata UHN pada menit ke-120 sesudah pemberian laktosa dan sebelum pemberian probiotik mati 36,00 (SD 10,18), nilai rata-rata UHN pada menit ke-120 sesudah pemberian laktosa dan sesudah pemberian probiotik mati menurun ke 20,30 (SD 8,86). Dari hasil uji statistik menggunakan uji t-berpasangan didapatkan perbedaan bermakna $(p<0,001)$ (Tabel 4).

Hasil pengujian rata-rata UHN sesudah pemberian probiotik hidup pada menit ke-120 22,13 (SD 12,41), sedangkan hasil pengujian rata-rata sesudah pemberian probiotik mati pada menit ke-120 adalah 20,30 (SD 8,86). Uji statistik menunjukkan tidak terdapat perbedaan antara kelompok yang mendapat probiotik hidup pada menit ke-120 dengan kelompok yang mendapat probiotik mati pada menit ke-120 dengan uji t-independen $(p=0,453)$ (Tabel 4$)$.

\section{Diskusi}

Prevalensi malabsorpsi laktosa di 5 SDN Kecamatan Tuminting, 86 anak $(66,5 \%)$ di antara 130 anak yang diteliti lebih tinggi dari penelitian Hegar $\mathrm{dkk}^{23}$ di Jakarta, 57,1\%. Perbedaan mungkin disebabkan oleh adaptasi yang lebih baik dari anak yang tinggal di Jakarta terhadap susu yang mengandung laktosa daripada anak yang tinggal di Manado.

Anak dengan status gizi kurang dan gizi buruk tidak diikutsertakan dalam penelitian karena kedua keadaan tersebut dapat disertai atrofi dari mukosa usus 
dan pengurangan dari produksi laktase. ${ }^{2}$ Probiotik diberikan selama dua minggu karena dari penelitian sebelumnya oleh Arifin $\mathrm{dkk}^{16}$ dan Kocian $\mathrm{dkk}^{24}$ menemukan bahwa penggunaan probiotik selama dua minggu meningkatkan toleransi terhadap laktosa dengan menurunkan $95 \%$ gejala intoleransi laktosa dan terdapat perubahan $85,7 \%$ dari nilai $U H N$ positif ke negatif.

Gejala malabsorpsi laktosa yang paling sering muncul sebelum pemberian probiotik (Tabel 2) adalah nyeri perut 55 anak (69,6\%) dengan 10 anak (13,9\%) mempunyai lebih dari satu gejala. Penelitian sebelumnya mendapatkan bahwa muntah dan kembung timbul 30 menit setelah laktosa dicerna, sedangkan nyeri perut, flatus, borborygmic atau diare timbul 1-2 jam sesudah laktosa dicerna. ${ }^{25}$ Sepuluh anak dengan peningkatan UHN tidak mempunyai gejala dari intoleransi laktosa, karena malabsorpsi laktosa ataupun intoleransi laktosa tergantung dari banyak faktor termasuk waktu pengosongan lambung dan waktu singgah di usus halus, aktivitas enzim laktase di usus, sensitivitas dari flora usus serta jumlah, frekuensi dan cara laktosa di konsumsi. ${ }^{26}$ Kemungkinan terjadinya positif palsu pada studi ini sudah diminimalkan dengan kriteria eksklusi.

Gejala klinis berkurang atau menghilang sesudah mendapat probiotik. Spesies probiotik dapat memproduksi antibiotik secara alamiah yang mempunyai spektrum aktivitas yang luas, mempunyai kemampuan untuk menghasilkan antimikroba yang dapat mengeliminasikan banyak bakteri gram negatif, meningkatkan aktivitas enzim laktase di usus, dan pemecahkan laktosa. ${ }^{9-12}$

Hasil dari pemeriksaan UHN sebelum dan sesudah mendapat probiotik hidup pada menit ke120 tertera pada Tabel 4. Hasil yang di dapat dengan menggunakan uji t-berpasangan sangat berbeda signifikan $(p<0,001)$. Hasil ini sama dengan hasil UHN sebelum dan sesudah mendapat probiotik mati pada menit ke-120. Hasil yang di dapat dengan menggunakan uji t-berpasangan sangat berbeda signifikan $(p<0,001)$. Tetapi hasil dari perbedaan antara kelompok sesudah mendapat probiotik hidup dan probiotik mati dengan tes UHN pada menit ke120 ketika di analisis menggunakan uji t-independen, tidak didapatkan perbedaan signifikan di antara kedua kelompok. ( $\mathrm{P}=0,453)$.

Hasil ini sama dengan penelitian oleh Saviano $\mathrm{dkk}^{27}$ di Paris, Perancis terhadap 16 subjek (20-33 tahun) dengan UHN positif untuk malabsorpsi laktosa, sesudah dua minggu mendapat probiotik dari yoghurt terdapat perubahan secara signifikan dari UHN. Penelitian lain dilakukan oleh Shermak $\mathrm{dkk}^{28}$ di Baltimore, Amerika pada 23 pasien (4-16 tahun) dengan malabsorpsi laktosa, sesudah diberikan probiotik didapatkan perubahan hasil UHN secara signifikan. Penelitian lain oleh Lin MY $\mathrm{dkk}^{29} \mathrm{di}$ Amerika dengan 10 pasien (24-40 tahun) dengan positif malabsorpsi laktosa, didapatkan sesudah menerima suplemen yoghurt terdapat perbedaan signifikan antara kelompok yang mendapat terapi dan kontrol. Penelitian lebih lanjut oleh Lin MY $\mathrm{dkk}^{30} \mathrm{di}$ Amerika menyimpulkan bahwa pemberian probiotik dapat menurunkan gejala intoleransi laktosa. Penelitian lain oleh Arifin $\mathrm{dkk}^{16}$ di Jakarta pada 42 murid SLTPN, sesudah minum susu yang mengandung probiotik terdapat perbedaan bermakna pada hasil UHN dari positif menjadi negatif $85,7 \%$.

Disimpulkan bahwa penggunaan probiotik hidup ataupun mati dapat menyebabkan perubahan pada metabolisme laktosa dengan interfensi dari aktivitas enzim $\beta$-galactosidase (enzim lactase). Di samping itu probiotik juga memproduksi hasill metabolisme berupa asam laktat, hidrogen peroksidasi, bakteriosin, bile salt hydrolase dan peptidoglikan serta berkompetisi dengan agen penyakit dengan cara melakukan blok reseptor maupun meningkatkan sistem kekebalan tubuh pada saluran cerna. ${ }^{31}$ Selama periode penelitian tidak terdapat efek samping pada anak-anak yang mendapat probiotik hidup maupun probiotik mati. Jadi, pemberian probiotik hidup maupun probiotik mati selama 2 minggu, efektif dalam mengobati anak dengan malabsorbsi laktosa, tampak dari penurunan nilai UHN, namun tidak terdapat perbedaan antara kedua kelompok serta tidak terdapat efek samping selama studi ini.

\section{Daftar Pustaka}

1. Hay WW. Gastrointestinal tract. Dalam: Hay WW, Levin MJ, Sondheimer JM, penyunting. Current Pediatric Diagnosis \& Treatment, Edisi ke-18. New York: Lange Medical books/McGraw-Hill; 2007.h.622-9.

2. Heyman MB. Lactose intolerance in infants, children and adolescents (AAP). Pediatrics 2006;118:1279-85.

3. Rauf S, Albar H, Adoe TH, Hasanuddin A, penyunting. Fisiologi Laktosa. Dalam: Simposium Nasional Nefrologi 
Anak VII dan Pertemuan Ilmiah Berkala Ilmu Kesehatan Anak VIII FK UNHAS. Makassar, 26-27 Juni 1998.

4. Montalto M, Curigliano V, Santoro L, Vastola M, Cammarota G, Manna R, dkk. Management and treatment of lactose malabsorption. Word J Gastroenterology 2006 ;12:187-91.

5. Warouw SM. Laktosa Malabsorpsi. Dalam: Buku Pedoman Diagnosis dan Terapi FK UNSRAT Manado. Bagian Ilmu Kesehatan Anak FK UNSRAT 2001:37.

6. Wilson J. Milk intolerance: Lactose intolerance and cow's milk protein allergy. Newborn and infant nursing reviews, 2005;5:203-7.

7. Dharmasetiawani N. Aktivitas laktase pada neonatus. Buletin Perinasia tahun XII, Nomor 1, Edisi Maret 2005.

8. Wikipedia. Lactose intolerance. From lactose Int $\&$ BHT\Lactose_files\link.htm. Search in 17-8-2007.

9. Subijanto MS, Ranuh R. Probiotik pada anak sehat dan sakit. Dalam: Permono HB, Kaspan MF, Soegijanto HS, Soejoso DA, Narendra MB, Noer S, penyunting. Kapita Selekta Ilmu Kesehatan Anak IV: "Hot topics in Pediatrics”. Surabaya: Intellectual Club; 2005.h.39-54.

10. Sudarmo SM. Management of infant diarrhea with highlactose probiotic containing formula. Southeast Asian J Trop Med Public Health 2003;34:845-8.

11. Rolfe RD. The role of probiotic cultures in the control of gastrointestinal health. J Nutr 2000; 130 (2S Suppl): 396S-402S.

12. Young RI, Huffman S. Probiotic use in children. J Pediatric Health Care 2003;17:277-83.

13. Talwalkar A and Kailasapathy K. A review of oxygen toxicity in probiotic yogurts: influence on the survival of probiotic bacteria and protective techniques. Dalam : Comprehensive reviews in food science and food safety 2004;3:117-23.

14. Dehkordi N, Rao DR, Warren AP, Chawan CB. Lactose malabsorption as influenced by chocolate milk, skim milk, sucrose, whole milk, and lactic cultures. J Am Dietetic Assoc 1995;95:484-6.

15. Mustapha A, Jiang $T$, Savaiano DA. Improvement of lactose digestion by humans following ingestion of unfermented acidophilus milk: influence of bile sensitivity, lactose transport, and acid tolerance of lactobacillus acidophilus. J Dairy Sci 1997;80:1537-45.

16. Arifin Z, Boediarso A, Tambunan T. Probiotic treatment in children with lactose intolerance. Dalam: Garna H, Nataprawira H. Abstrak Konika XIII Bandung 4-7 Juli 2005. Bandung, IDAI, 2005.h.511.

17. Warouw S, Manoppo J, Gunawan S, Kosim S.
Comparison between lived and tyndallized probiotic effectivity as therapy of acute diarrhea on children aged 4-60 months. In : Abstract PIT III. Yogyakarta, 6-9 Mei 2007. Yogyakarta: IDAI; 2007.h. 431.

18. Tlaskal P, Schramlova A, Kokesova J, Adamus D, Bubakova D, Kocnarova $\mathrm{N}$ dkk. Probiotics in the treatment of diarrhea disease of children. Nafat 2006;3:25-8.

19. Xiao SD, Lu H, Jiang SH, Liu HY, Wang GS, Xu GM dkk. Multicenter, randomized, controlled trial of heat killed lactobacillus acidophilus LB in patients with chronic diarrhea. Advances in therapy 2003; 20:25360 .

20. Madiyono B, Moeslichan S, Sastroasmoro S, Budiman I, Purwanto SH. Perkiraan jumlah sampel. Dalam : Sastroasmoro S, Ismail S, penyunting. Dasar Metodologi Penelitian. Edisi pertama. Jakarta: Binarupa Aksara; 1995. h.187-212.

21. Pusponegoro HD, Hadinegoro SR, Firmanda D. Standard Terapi Ilmu Kesehatan Anak. Edisi 1, 2004. Jakarta: Ikatan Dokter Anak Indonesia; 2004.

22. Di Stefano M, Missanelli A, Miceli E, Strocchi A, Corazza GR. Hydrogen breath test in the diagnosis of lactose malabsorption : Accuracy of new versus conventional criteria. J Lab Clin Med 2004;313-7.

23. Hegar B, Niken PY, Pramita G, dkk. Aktivitas enzim laktase pada murid sekolah dasar. Dalam : Firmansyah A, Trihono PP, Oswari H, dkk. Abstrak Konika XI. Bukit Tinggi 4-7 Juli 1999. Jakarta; IDAI, 1999. h. 8

24. Kocian J. Further possibilities in the treatment of lactose intolerance : Lactobacilli. Prakticky Lekar 1994;74:212-4.

25. Buller HA. Lactase phlorizin hydrolyses : a review of the literature [dissertation]. Netherland: University of Amsterdams; 1990.

26. Montes RG, Perman JA. Lactose intolerance. Postgrad med 1991:89;175-84.

27. Savaiano DA, Smith DE, Martini MC. Lactose digestion from flavored and frozen yogurts, milk, and ice cream by lactase-deficient persons. Am J Clin Nutr 1987;46:63640.

28. Shermak MA, Saavedra JM, Jackson TL, Huang SS, Bayless TM, Perman JA. Effect of yogurt an symptoms and kinetics of hydrogen production in lactose-malabsorbing children. Am J Clin Nutr 1995;62:1003-6.

29. Lin MY, Savaiano D, Harlander S. Influence of non fermented dairy products containing bacterial starter cultures on lactose maldigestion in humans. J Dairy Sci 1991;74:87-95. 
30. Lin MY, Yen CL, Chen SH. Management of lactose maldigestion by consuming milk containing lactobacilli. Digestive Diseases \& Sciences 1998; 43:133-7.
31. Symposium highlight treatment and prevention diarrhea with tyndallized LAB. Rumah Sakit Budi Kemuliaan Batam, 18 Juni 2006. 